\title{
The Impact of Electronic Devices on the Female Students' Interpersonal Relationships and their Academic Achievement
}

\author{
Khaled Ahmad Alkandari \\ College of Basic Education \\ (The Public Authority for Applied Education and Training) \\ Kuwait \\ Muhammad Khaled Al-Alawneh \\ College of Education \\ Curriculum and Instruction \\ Yarmouk University, Jordan
}

\begin{abstract}
The study intends to investigate the perception of female students concerning the use of electronic devices and multimedia. It is because the use of electronic devices has now been a common practice among both female and male students. The time spent on electronic devices may create a significant impact on students' academic achievement. It also assesses the relationship between electronic devices and the academic achievement of the students. It recruited 271 females 6th grade to 12th grade students from 20 schools in Mubarak Educational Area, Kuwait. Data were collected through the questionnaire and were statistically analyzed using the Statistical Package of Social Sciences (SPSS) Version 20.0. The results depicted no use of electronic devices and social media for co-operative learning. It also showed that students rarely used social media for communicating with their teachers, both academically and personally. It found a significant difference concerning their academic achievement and involvement, which was restricted to their family members.
\end{abstract}

Keywords: Academic Achievement; Electronic Devices; Female Students; Interpersonal Relationships; Perceptions.

\section{Introduction}

In the highly advanced technological environment, the relationship between the students, parents, friends, and teachers is of great importance. The continuous accessibility and availability of the devices promote the youngsters to manipulate it as per their need and desire despite the parental control (Nikken \& Schols, 2015). Parents and academicians alike perceive that they should set a 
parameter concerning the use of technology for limiting the hours' children devote to technology (Nikken et al., 2015). Hongsanguasri \& Kiatrungrit (2014) on the secondary school students showed that the majority had easy access to various electronic media devices with minimal parental control.

The technological fear is perceived to exist due to its impact on the relationship and interaction among the people. Demirci, Akgönül, \& Akpinar (2015) observe that the children's time on multimedia devices is comparatively high as compared to the time they spend to study and perform some productive tasks. Al-Barashdi, Bouazza, \& Jabur (2015) highlighted that students' personality and lifestyle has an increasing effect on the use of mobile phones among female students. The two factors are significant in determining the individual dependence over electronic devices, which demonstrate their limits of using such devices. The dependency of mobile phones among female users is positively associated with the Mobile Phone Dependency Questionnaire. It further illustrated the relatedness of the mobile phone dependency on the female students' attitudes towards sociability and inappropriate lifestyle. Various studies emphasize that the use of technological devices does not pose any detrimental effect on students and children (Raskauskas \& Stoltz, 2007; Rosen et al., 2014). The primary idea posed is to effectively use the tool for accessing different knowledge sources, facilitating daily activities, and effectively contributing to the workplace. Englund, Olofsson, \& Price (2017) stresses the integration of technology into teaching and learning processes. Nowell (2012) showed that technological integration is likely to improve student's motivation, engagement, and learning capabilities. Not only this, but the online availability of the teacher further eases the learning process. De Sousa, Richter, \& Nel (2017) denotes that technology integration in the classroom encourages students towards learning and helps in enriching their educational experience.

Easy access to the internet has provided the younger generation an exposure towards different types of content. It has provided feasibility to students in getting educational content. Whereas, in other cases, students mainly interact with unhealthy content that may negatively influence their mental abilities. Such content exposes both male and female students. It pinpoints the paucity of teachers and school management in providing the necessary counselling to students regarding the favourable usage of the internet (Rabiu, Muhammed, Umaru, \& Ahmed, 2016). Also, inadequate methods of teaching, lack of parents', and teachers' concern over unnecessary mobile phone usage, along with the use of competitive teaching materials, could be a cause associated with students' use of mobile phone devices for educational purposes.

In various virtual learning spaces, technology serves as a useful source in providing chances for communication that is associated with educational purposes (Gdanetz et al., 2018). Fuller \& Joynes (2015) focused on the current social, educational, and health policies concerning the use of mobile technology devices. The results suggested that teachers should focus less on the implementation of technology for learning; rather, they should focus on the development of mobile learning in curricula. This aspect has been termed as 
comprehensive, meaningful, sustainable, and compulsory in various educational settings (Fuller et al., 2015).

Various studies report that the primary challenge experienced by parents and teachers is to determine how to limit technology use among children (Helou \& Rahim, 2014; Shifflet \& Weilbacher, 2015). The decrease in the use of electronic devices and an increase in literacy activity reduces the risk of dyslexia among children (He et al., 2014). For various female students, the use of electronic devices such as cell phones provides usefulness in arranging various educational events. Update educational information is delivered to the students through social networking sites. Besides this, students consider it easy to organize meetings that need extensive and detailed communications. Social media sites and applications help in communicating the messages. In other words, the use of electronic devices integrates quick responses among female students regarding their educational practices (Eginli \& Tas, 2018). Thereby, the present study intends to explore the impact electronic devices pose on the academic achievement of female students. It also focuses on the differences concerned with the pro and cons of electronic devices as perceived by the female students. The dynamic technology integration has changed, which expands to social, political, academic, and political spheres of an individual's life (Lee, 2013). De Loen- Abao, Boholano, \& Dayagbil (2015) documented that the use of technology and multimedia has changed the attitudes and habits of individuals. A similar change is observed within the schools in Kuwait and its neighbouring countries, where benefits associated with the electronic devices are communicated.

The use of technological devices is observed in regular curriculum activities of the Kuwaiti students. However, De Loen et al. (2015) highlights that the same devices pose an adverse impact when used for insulting, dishonest practices, and educational technology. Several studies report the integration of technology in education for enhancing educational outcomes (Bester \& Brand, 2013; De Sousa et al., 2017).

Over the past two decades, an increased inclination is observed for the use of electronic devices, more precisely among the young female students (Eastman, 2016). To contribute to the existing body of literature, the present study examines the impact of social media on the female students' interpersonal skills and academic achievement in Kuwait. Thus, the study aims to answer the following;

- What is the impact of social networks on the interaction of female students with their family, friends, and teachers?

- Does there exist a statistically significant difference between female students' use of social networks and academic achievement?

- Does there exist a statistically significant difference between the female students' use of social network and grade level (Such as 6th to 12th)?

- What are the advantage and disadvantages of social media networks concerning female students?

The present study is significant as it aims to investigate the issue of the use of electronic devices among various female students studying in institutions of 
Kuwait. Previous studies have discussed the idea in general perspectives that are associated to students regardless of gender. The present study is significant in this regard, as it separates the given information based on gender, providing a more in-depth overview of the previously mentioned information. The study provides an active contribution to the existing literature, as it has specifically worked on a single-gender, i.e., female student. Results proposed by the study are significant in understanding the current use of electronic devices, along with their extent and nature of usage.

\section{Material and Methods}

\subsection{Study Design}

The study has employed a cross-sectional analysis to investigate the perception of female students regarding the use of electronic devices.

\subsection{Study Participants}

The study population consists of the female students that were enrolled from sixth grade to twelfth grade in the Mubarak Educational Area, Kuwait. This study population is selected based on relevance to the study objective. Initially, a survey link was shared only on WhatsApp group of the female students, by the consent of the school principal. This post comprised of the survey invite, a welcome message, and the instructions for filling the questionnaire.

\subsection{Study Tool}

The data were collected through an online survey, which constitutes five parts and seventeen items. The questionnaire was related to the student's relationship with the consumer, peers, teachers, and family. The first question included three sub-questions, i.e., personal details concerning school name, grade as well as academic achievement, and account selection (i.e., Facebook, WhatsApp, Twitter, etc.). Secondly, it collected information concerning the nature of internet usage among the students. This included options such as Instagram, WhatsApp, Twitter, Google Plus, Facebook, email, YouTube, research, and no usage). The second item of the questionnaire also assessed the frequency of internet use among the students concerning their use for assignment and homework. Whereas, the remaining items were related to the relationship of the students with their colleagues, family, teachers, and community.

\subsection{Data Collection}

The survey focused on the analysis of the student's perceptions concerning their technological use. The options vary, such as some were based on a 5-point Likert scale, some used yes or no, and some drop-down or an exit menu.

\subsection{Data Analysis}

The data obtained through the questionnaire was analysed using the Statistical Package of Social Sciences (SPSS) version 20.0. The SPSS version 20.0 is one of the widely used statistical analysis tools which helps to solve different research problems (IBM Official Website, 2018). The collected data is first input into it, which is then followed by the application of the required test. The data were 
analysed by grouping the students with similar answers. Moreover, the crosstabulation (chi-square test method) is used for investigating the impact of social networks on the student's grade. It also tabulated the student's responses concerning their use of internet and multimedia devices. The chi-square method is used to highlight the significance of association concerning the use of social networks and the grades of the students (Sharpe, 2015).

Accordingly, the section below presents the implementation of the detailed methods and the derived results. Initially, the electronic devices most frequently used by the Kuwaiti female students are presented following analysis of their usage purpose and frequency of internet use. It also shows the association between students' achievement and the degree of social networks use and its impact on their grades.

\section{Results and Discussion}

The study sample comprised of 271 female students. The responses concerning the use of the most frequent electronic device (Table 1). The analysis showed that majority of the students used Tablet $(n=175)$, following Mobile $(n=168)$, Laptop $(n=60)$, iPod $(n=46)$, and Wii $(n=11)$. Whereas, the use of Xbox and PlayStation was found to be limited, such as only five students had PlayStation; while, one of them had the hands-on Xbox. While two students did not respond.

Table 1: Female Students used Electronic Devices

\begin{tabular}{|c|c|c|c|c|c|c|c|c|c|}
\hline $\begin{array}{c}\text { Electronic } \\
\text { device }\end{array}$ & Tablet & Mobile & Laptop & iPod & Wii & $\begin{array}{c}\text { Play } \\
\text { station }\end{array}$ & $\begin{array}{c}\text { Other } \\
\text { devices }\end{array}$ & N/A & Xbox \\
\hline Availability & 175 & 168 & 60 & 46 & 11 & 5 & 5 & 2 & 1 \\
\hline
\end{tabular}

Table 2 has shown the percentage and frequency distribution of the sample concerning the female students' purpose for using internet. It shows that most students responded Yes to "I use the Internet to socialize with my classmates" $(90.8 \%)$, while $9.2 \%$ of students reported no. The results of the given study do not align with the findings of Li, Palonen, Lehtinen, \& Hakkarainen (2019). According to the results, female students preferred face to face communication rather than communication integrated through social media websites. Besides this, female students are more concerned about providing educational guidance through Facebook. The study further highlighted that female student interact with their peers on Facebook.

Table 2 indicates that family photo exchange was low among the female students $(38 \%)$, while $68.6 \%$ had family groups on WhatsApp. Dweikat (2019) proposed contradicting results where female students were more comfortable in peer interaction on WhatsApp. However, the majority of female students reported that they did not practice personal photo sharing on WhatsApp. Rather, they mainly focused on sharing pictures, photos, messages that were associated with everyday classroom lessons, and worksheets.

Moreover, female participants stated that a high percentage $(70.1 \%)$ of them were part of the girls group while $52.4 \%$ responded that there was no control on the internet usage at home, whereas, more than half of the participants state no 
commitment to any sort of control that is likely to be enforced by the parents. Cerretani, Iturrioz, \& Garay (2016) argued that female students ensured limited use of electronic devices in their leisure time. Participants were highly concerned about their academic performances that have automatically affected their usage of mobile and other electronic devices. Moreover, $18.6 \%$, i.e., a minimum number of students, were found in excessive usage of mobile phones. While $20 \%$ of participants acknowledged that the mobile phone had created a negative impact on their academic performances.

The sharing of nice thoughts and ideas on social networks was expressed by $62 \%$, such as Facebook. These findings are in contrast to those provided by Alhazmi \& Rahman (2013), which showed increased use of Facebook among female students. It revealed that it is associated with keeping in touch with their peers $(88.6 \%)$. Others were mainly concerned about posting things that are related to their life happenings. However, a very low percentage was recorded for academic purposes, i.e., $38.1 \%$. While only $10 \%$ of students shared that Facebook helps share and discuss academic work.

Table 2. Female Participants and their Purpose of Internet and Multimedia Devices Usage

\begin{tabular}{|c|c|c|c|}
\hline Item & \multicolumn{2}{|c|}{ Response } & $\%$ \\
\hline \multirow{2}{*}{$\begin{array}{l}\text { I make use of the internet to socialize with } \\
\text { classmates. }\end{array}$} & Yes & 264 & 90.8 \\
\hline & No & 25 & 9.2 \\
\hline \multirow{2}{*}{$\begin{array}{l}\text { I use the internet to share family photos } \\
\text { with my classmates. }\end{array}$} & Yes & 103 & 38 \\
\hline & No & 168 & 62 \\
\hline \multirow{2}{*}{$\begin{array}{l}\text { I am also a part of the family group on the } \\
\text { internet. }\end{array}$} & Yes & 189 & 68.7 \\
\hline & No & 82 & 30.3 \\
\hline \multirow{2}{*}{$\begin{array}{l}\text { I am a member of a family group so that I } \\
\text { can socialize with girls. }\end{array}$} & Yes & 190 & 70.1 \\
\hline & No & 81 & 29.9 \\
\hline \multirow{2}{*}{$\begin{array}{l}\text { Do you feel any kind of control while } \\
\text { using the internet at home? }\end{array}$} & Yes & 129 & 47.6 \\
\hline & No & 142 & 52.4 \\
\hline \multirow{2}{*}{$\begin{array}{l}\text { In case you feel control over the internet, } \\
\text { do you commit to it? }\end{array}$} & Yes & 120 & 44.3 \\
\hline & No & 151 & 55.7 \\
\hline \multirow[t]{2}{*}{ I share nice thoughts on social media. } & Yes & 168 & 62 \\
\hline & No & 103 & 38 \\
\hline Total & & 271 & 100 \\
\hline
\end{tabular}

Frequencies and percentages of the responses obtained from the students were calculated to answer the question, "In what terms are female students using social networks to interact with their teachers, friends, and family?" Table 3 has illustrated the participant's response concerning internet use. It shows that the internet was used by almost $48.0 \%$ for "sometimes" and the lowest percentage was $8 \%$ for "always" for homework using the internet. Results are endorsed by Pickering \& Bickerdike (2017), which illustrate that the use of Facebook among 
students has provided a positive impact on their educational achievements. Around $85 \%$ of the participants supported that Facebook served as an important tool in their learning processes.

An increased percentage of participants showed that the internet was rarely used for cooperative learning, which was lowest for never to the same question, i.e., $28.0 \%$ and $12.0 \%$, respectively. Manasijević, Živković, Arsić, \& Milošević (2016) provided similar views where Facebook is highly effective in collaborative activities among students regarding educational practices. Facebook was highly useful for sharing projects, homework, and ideas, etc.

The response to question 1 showed that never was selected by $38.7 \%$ for using the internet to socialize with the teacher, whereas always as responded by $5.2 \%$. Almost half the population showed that 50.2 percent had never used the internet for communicating with the teacher, whereas 5.5 percent had always used it for communicating with their teacher. Concerning the question, i.e., resending a message without ensuring the resource reliability was responded never (48.7 percent), while 9.2 percent always responded. Sheldon (2016) proposed contradicting results where the majority of the students have personal intentions in adding a teacher in the Facebook friends' list. Students, to get the answers related to examination questions, to try to communicate their teachers on such platforms.

Concerning "I am honest in the messages that I exchange with my classmates," the majority responded with always (52.8 percent), while 4.1 percent stated "Never." Lastly, for the question, "send messages that insult others," for which the majority of the students (58.7\%) responded, "Never," and only 3.8\% responded "always." The results are contradictory to those proposed by Castleman \& Page (2015), where text messaging was most common among teachers in comparison to female students. The context of the message was mainly associated with the students' progress and development.

Table 3. Frequency of Students Use of Internet

\begin{tabular}{|c|c|c|c|}
\hline Items & Response & Frequency & $\mathbf{\%}$ \\
\hline \multirow{4}{*}{$\begin{array}{c}\text { Internet use and self-learning } \\
\text { (doing my homework) }\end{array}$} & Never & 23 & 8.5 \\
\cline { 2 - 4 } & Rarely & 54 & 19.9 \\
\cline { 2 - 4 } & Sometimes & 130 & 48.0 \\
\cline { 2 - 4 } & Mostly & 42 & 15.5 \\
\cline { 2 - 4 } & Always & 22 & 8.1 \\
\hline \multirow{4}{*}{$\begin{array}{c}\text { Internet use and cooperation- } \\
\text { learning (doing homework with } \\
\text { my classmates) }\end{array}$} & Never & 34 & 12.5 \\
\cline { 2 - 4 } & Rarely & 76 & 28.0 \\
\cline { 2 - 4 } & Sometimes & 49 & 18.1 \\
\cline { 2 - 4 } & Mostly & 57 & 21.0 \\
\cline { 2 - 4 } & Always & 55 & 20.3 \\
\hline Internet use and socializing with & Never & 105 & 38.7 \\
\cline { 2 - 4 } my teachers & Rarely & 67 & 24.7 \\
\cline { 2 - 4 } & Sometimes & 58 & 21.4 \\
\cline { 2 - 4 } & Mostly & 27 & 10.0 \\
\cline { 2 - 4 } & Always & 14 & 5.2 \\
\hline
\end{tabular}




\begin{tabular}{|c|c|c|c|}
\hline \multirow{5}{*}{$\begin{array}{l}\text { Internet use for communicating } \\
\text { with teachers concerning } \\
\text { curriculum-related concerns. }\end{array}$} & Never & 136 & 50.2 \\
\hline & Rarely & 57 & 21.0 \\
\hline & Sometimes & 47 & 17.3 \\
\hline & Mostly & 16 & 5.9 \\
\hline & Always & 15 & 5.5 \\
\hline \multirow{5}{*}{$\begin{array}{l}\text { I send messages without } \\
\text { identifying the source's } \\
\text { reliability. }\end{array}$} & Never & 132 & 48.7 \\
\hline & Rarely & 56 & 20.7 \\
\hline & Sometimes & 58 & 21.4 \\
\hline & Mostly & 25 & 9.2 \\
\hline & Always & 0 & 0 \\
\hline \multirow{5}{*}{$\begin{array}{l}\text { I honestly share the information } \\
\text { with my classroom. }\end{array}$} & Never & 11 & 4.1 \\
\hline & Rarely & 17 & 6.3 \\
\hline & Sometimes & 30 & 11.1 \\
\hline & Mostly & 70 & 25.8 \\
\hline & Always & 143 & 52.8 \\
\hline \multirow{5}{*}{$\begin{array}{c}\text { I send insulting messages to } \\
\text { others }\end{array}$} & Never & 159 & 58.7 \\
\hline & Rarely & 63 & 23.2 \\
\hline & Sometimes & 24 & 8.9 \\
\hline & Mostly & 17 & 6.3 \\
\hline & Always & 8 & 3.0 \\
\hline
\end{tabular}

The Chi-Square was used to assess the answer to the question, "Is there a statistically significant difference between female students' degree of using social networks and their academic achievement?" Table 4 has presented the frequencies of the responses to investigate the relationship between the achievement of female students and the usage of social networks. The results depicted a statistically insignificant difference $(\alpha \leq 0.05)$ between different investigated issues. Students' perception of using the internet for self-learning, cooperation learning, and socialization with teachers and classmates has demonstrated an insignificant relationship between the use of the internet and academic achievement with the given difference of 21.80, 10.61, 1.94, and 24.96 respectively. Other variables include the parents' control over the use of the internet, their commitment towards the control, honesty in transferring information to other classmates, along with inappropriate messaging shares an insignificant relationship with academic achievements with the given value of $2.67,8.47,10.44$, and 19.21 respectively. Next includes female students seeking employment opportunities through social networks and reliability of resources in sharing various messages that share an insignificant relationship with academic performances with the given value of 2.35 and 11.88, respectively.

Table 4. Female Students' Achievement and the Degree of Social Networks Use

\begin{tabular}{|c|c|c|c|c|c|c|c|}
\hline \multirow{2}{*}{ Items } & Responses & \multicolumn{5}{|c|}{ Frequency } & \multirow{2}{*}{$\begin{array}{c}\text { Chi- } \\
\text { Square }\end{array}$} \\
\cline { 2 - 7 } & Weak & $\begin{array}{c}\text { Acceptab } \\
\text { le }\end{array}$ & Good & $\begin{array}{c}\text { Very } \\
\text { Good }\end{array}$ & Excellent & \\
\hline \multirow{2}{*}{$\begin{array}{c}\text { I use the } \\
\text { internet for } \\
\text { self- } \\
\text { learning } \\
\text { (doing my } \\
\text { homework) }\end{array}$} & Never & 8 & 3 & 2 & 0 & 8 & 21.80 \\
\cline { 2 - 7 } & Rarely & 20 & 14 & 0 & 0 & 20 & \\
\cline { 2 - 7 } & Sometimes & 44 & 24 & 3 & 1 & 44 \\
\hline
\end{tabular}




\begin{tabular}{|c|c|c|c|c|c|c|c|}
\hline \multirow[t]{2}{*}{ Items } & \multirow[t]{2}{*}{ Responses } & \multicolumn{5}{|c|}{ Frequency } & \multirow{2}{*}{$\begin{array}{l}\text { Chi- } \\
\text { Square }\end{array}$} \\
\hline & & Weak & $\begin{array}{c}\text { Acceptab } \\
\text { le }\end{array}$ & Good & $\begin{array}{l}\text { Very } \\
\text { Good }\end{array}$ & Excellent & \\
\hline \multirow{5}{*}{$\begin{array}{l}\text { I use the } \\
\text { internet for } \\
\text { cooperation } \\
\text {-learning } \\
\text { (doing } \\
\text { homework } \\
\text { with my } \\
\text { classmates) }\end{array}$} & Never & 10 & 9 & 0 & 0 & 10 & \multirow[t]{5}{*}{10.61} \\
\hline & Rarely & 27 & 13 & 2 & 1 & 27 & \\
\hline & Sometimes & 23 & 8 & 2 & 0 & 23 & \\
\hline & Mostly & 19 & 14 & 1 & 1 & 19 & \\
\hline & Always & 25 & 8 & 2 & 1 & 25 & \\
\hline \multirow{5}{*}{$\begin{array}{l}\text { I use the } \\
\text { internet to } \\
\text { socialize } \\
\text { with my } \\
\text { classmates }\end{array}$} & Never & 10 & 6 & 0 & 0 & 10 & \multirow[t]{5}{*}{1.30} \\
\hline & Rarely & 94 & 46 & 7 & 3 & 94 & \\
\hline & Sometimes & 64 & 32 & 4 & 3 & 64 & \\
\hline & Mostly & 40 & 20 & 3 & 0 & 40 & \\
\hline & Always & 46 & 15 & 5 & 2 & 46 & \\
\hline \multirow{5}{*}{$\begin{array}{l}\text { I exchange } \\
\text { family } \\
\text { photos with } \\
\text { my } \\
\text { classmates }\end{array}$} & Never & 19 & 19 & 0 & 0 & 19 & \multirow[t]{5}{*}{1.94} \\
\hline & Rarely & 26 & 7 & 2 & 1 & 26 & \\
\hline & Sometimes & 9 & 4 & 0 & 0 & 9 & \\
\hline & Mostly & 4 & 7 & 0 & 0 & 4 & \\
\hline & Always & 50 & 24 & 5 & 2 & 50 & \\
\hline \multirow{5}{*}{$\begin{array}{l}\text { I use the } \\
\text { internet for } \\
\text { socializing } \\
\text { with my } \\
\text { teachers }\end{array}$} & Never & 21 & 14 & 0 & 0 & 21 & \multirow[t]{5}{*}{24.96} \\
\hline & Rarely & 22 & 8 & 1 & 1 & 22 & \\
\hline & Sometimes & 6 & 2 & 0 & 0 & 6 & \\
\hline & Mostly & 5 & 4 & 1 & 0 & 5 & \\
\hline & Always & 41 & 7 & 0 & 0 & 41 & \\
\hline \multirow{5}{*}{$\begin{array}{l}\text { I use the } \\
\text { internet to } \\
\text { communicat } \\
\text { e with my } \\
\text { teachers in } \\
\text { curriculum- } \\
\text { related } \\
\text { issues }\end{array}$} & Never & 63 & 45 & 7 & 3 & 63 & \multirow[t]{5}{*}{8.78} \\
\hline & Rarely & 32 & 14 & 2 & 0 & 32 & \\
\hline & Sometimes & 72 & 38 & 5 & 3 & 72 & \\
\hline & Mostly & 56 & 23 & 4 & 1 & 56 & \\
\hline & Always & 48 & 29 & 3 & 2 & 48 & \\
\hline \multirow{5}{*}{$\begin{array}{c}\text { I am part of } \\
\text { just a family } \\
\text { group }\end{array}$} & Never & 49 & 27 & 6 & 1 & 49 & \multirow[t]{5}{*}{15.72} \\
\hline & Rarely & 55 & 25 & 1 & 2 & 55 & \\
\hline & Sometimes & 54 & 25 & 3 & 0 & 54 & \\
\hline & Mostly & 17 & 13 & 1 & 1 & 17 & \\
\hline & Always & 20 & 9 & 3 & 2 & 20 & \\
\hline \multirow{5}{*}{$\begin{array}{l}\text { I am part of } \\
\text { the family } \\
\text { group of } \\
\text { girls only. }\end{array}$} & Never & 13 & 5 & 0 & 0 & 13 & \multirow[t]{5}{*}{1.59} \\
\hline & Rarely & 54 & 25 & 3 & 0 & 54 & \\
\hline & Sometimes & 3 & 3 & 0 & 0 & 3 & \\
\hline & Mostly & 9 & 3 & 0 & 0 & 9 & \\
\hline & Always & 11 & 3 & 1 & 0 & 11 & \\
\hline \multirow{3}{*}{$\begin{array}{l}\text { Do you face } \\
\text { any kind of } \\
\text { control }\end{array}$} & Never & 28 & 10 & 3 & 1 & 28 & \multirow[t]{3}{*}{2.67} \\
\hline & Rarely & 53 & 33 & 3 & 2 & 53 & \\
\hline & Sometimes & 58 & 31 & 3 & 1 & 58 & \\
\hline
\end{tabular}




\begin{tabular}{|c|c|c|c|c|c|c|c|}
\hline \multirow{4}{*}{$\begin{array}{l}\text { while using } \\
\text { the } \\
\text { internet? }\end{array}$} & \multirow[t]{2}{*}{ Responses } & \multicolumn{5}{|c|}{ Frequency } & \multirow{4}{*}{$\begin{array}{l}\text { Chi- } \\
\text { Square }\end{array}$} \\
\hline & & Weak & $\begin{array}{c}\text { Acceptab } \\
\text { le }\end{array}$ & Good & $\begin{array}{l}\text { Very } \\
\text { Good }\end{array}$ & Excellent & \\
\hline & Mostly & 22 & 13 & 4 & 0 & 22 & \\
\hline & Always & 12 & 5 & 0 & 1 & 12 & \\
\hline \multirow{5}{*}{$\begin{array}{c}\text { In case you } \\
\text { experience } \\
\text { control, } \\
\text { then do you } \\
\text { commit to } \\
\text { it? }\end{array}$} & Never & 10 & 1 & 0 & 1 & 10 & \multirow[t]{5}{*}{8.47} \\
\hline & Rarely & 2 & 2 & 0 & 0 & 2 & \\
\hline & Sometimes & 40 & 19 & 2 & 0 & 40 & \\
\hline & Mostly & 64 & 33 & 5 & 3 & 64 & \\
\hline & Always & 8 & 3 & 2 & 0 & 8 & \\
\hline \multirow{5}{*}{$\begin{array}{c}\text { I send } \\
\text { messages } \\
\text { without } \\
\text { identifying } \\
\text { the source's } \\
\text { reliability. }\end{array}$} & Never & 20 & 14 & 0 & 0 & 20 & \multirow[t]{5}{*}{11.88} \\
\hline & Rarely & 44 & 24 & 3 & 1 & 44 & \\
\hline & Sometimes & 22 & 6 & 1 & 2 & 22 & \\
\hline & Mostly & 10 & 5 & 1 & 0 & 10 & \\
\hline & Always & 10 & 9 & 0 & 0 & 10 & \\
\hline \multirow{5}{*}{$\begin{array}{l}\text { I honestly } \\
\text { share the } \\
\text { information } \\
\text { with my } \\
\text { classroom. }\end{array}$} & Never & 27 & 13 & 2 & 1 & 27 & \multirow[t]{5}{*}{10.44} \\
\hline & Rarely & 23 & 8 & 2 & 0 & 23 & \\
\hline & Sometimes & 19 & 14 & 1 & 1 & 19 & \\
\hline & Mostly & 25 & 8 & 2 & 1 & 25 & \\
\hline & Always & 10 & 6 & 0 & 0 & 10 & \\
\hline \multirow{5}{*}{$\begin{array}{c}\text { I send } \\
\text { insulting } \\
\text { messages to } \\
\text { others }\end{array}$} & Never & 94 & 46 & 7 & 3 & 94 & \multirow[t]{5}{*}{19.21} \\
\hline & Rarely & 64 & 32 & 4 & 3 & 64 & \\
\hline & Sometimes & 40 & 20 & 3 & 0 & 40 & \\
\hline & Mostly & 46 & 15 & 5 & 2 & 46 & \\
\hline & Always & 19 & 19 & 0 & 0 & 19 & \\
\hline \multirow{5}{*}{$\begin{array}{l}\text { I use the } \\
\text { internet in a } \\
\text { way to get } \\
\text { employmen } \\
\mathrm{t} \text { through } \\
\text { social } \\
\text { networks. }\end{array}$} & Never & 26 & 7 & 2 & 1 & 26 & \multirow[t]{5}{*}{2.35} \\
\hline & Rarely & 9 & 4 & 0 & 0 & 9 & \\
\hline & Sometimes & 4 & 7 & 0 & 0 & 4 & \\
\hline & Mostly & 50 & 24 & 5 & 2 & 50 & \\
\hline & Always & 21 & 14 & 0 & 0 & 21 & \\
\hline
\end{tabular}

*Statistically Significant at $(0.05 \geq \alpha)$

Table 5. Female Students' Grades and Social Networks Use

\begin{tabular}{|c|c|c|c|c|c|c|c|c|c|}
\hline \multirow[t]{2}{*}{ Items } & \multirow[t]{2}{*}{ Response } & 6th & 7th & 8th & 9th & 10th & 11th & 12th & \multirow[t]{2}{*}{$\begin{array}{c}\text { Chi- } \\
\text { Square }\end{array}$} \\
\hline & & \multicolumn{7}{|c|}{ Frequencies } & \\
\hline \multirow{5}{*}{$\begin{array}{l}\text { I use the internet } \\
\text { for self-learning } \\
\text { (doing my } \\
\text { homework) }\end{array}$} & Never & 1 & 6 & 2 & 4 & 4 & 4 & 3 & \multirow[t]{5}{*}{ *38.97 } \\
\hline & Rarely & 8 & 11 & 12 & 7 & 7 & 5 & 7 & \\
\hline & Sometimes & 22 & 18 & 29 & 31 & 31 & 12 & 13 & \\
\hline & Mostly & 2 & 5 & 7 & 12 & 12 & 1 & 7 & \\
\hline & Always & 0 & 2 & 7 & 5 & 5 & 2 & 6 & \\
\hline
\end{tabular}




\begin{tabular}{|c|c|c|c|c|c|c|c|c|c|}
\hline Items & Response & 6th & 7th & 8th & 9th & 10th & 11th & 12th & \multirow[t]{2}{*}{$\begin{array}{l}\text { Chi- } \\
\text { Square }\end{array}$} \\
\hline & & \multicolumn{7}{|c|}{ Frequencies } & \\
\hline \multirow{5}{*}{$\begin{array}{l}\text { Internet use and } \\
\text { cooperation- } \\
\text { learning (doing } \\
\text { homework with } \\
\text { my classmates) }\end{array}$} & Never & 3 & 6 & 7 & 8 & 8 & 6 & 2 & \multirow[t]{5}{*}{25.05} \\
\hline & Rarely & 8 & 14 & 9 & 20 & 20 & 4 & 16 & \\
\hline & Sometimes & 7 & 6 & 15 & 7 & 7 & 5 & 4 & \\
\hline & Mostly & 7 & 7 & 10 & 14 & 14 & 4 & 9 & \\
\hline & Always & 8 & 9 & 16 & 10 & 10 & 5 & 5 & \\
\hline \multirow{2}{*}{$\begin{array}{l}\text { Internet use and } \\
\text { socializing with } \\
\text { my classmates }\end{array}$} & No & 3 & 3 & 8 & 5 & 5 & 3 & 1 & \multirow[t]{2}{*}{4.39} \\
\hline & Yes & 30 & 39 & 49 & 54 & 54 & 21 & 35 & \\
\hline \multirow{2}{*}{$\begin{array}{l}\text { I share family } \\
\text { photos with my } \\
\text { classmates. }\end{array}$} & No & 24 & 27 & 30 & 43 & 43 & 13 & 21 & \multirow[t]{2}{*}{7.60} \\
\hline & Yes & 9 & 15 & 27 & 16 & 16 & 11 & 15 & \\
\hline \multirow{5}{*}{$\begin{array}{l}\text { Internet use and } \\
\text { socializing with } \\
\text { my teachers }\end{array}$} & Never & 14 & 11 & 25 & 20 & 20 & 11 & 15 & \multirow[t]{5}{*}{26.89} \\
\hline & Rarely & 10 & 11 & 13 & 13 & 13 & 4 & 11 & \\
\hline & Sometimes & 4 & 11 & 8 & 16 & 16 & 7 & 9 & \\
\hline & Mostly & 5 & 7 & 4 & 7 & 7 & 1 & 0 & \\
\hline & Always & 0 & 2 & 7 & 3 & 3 & 1 & 1 & \\
\hline \multirow{5}{*}{$\begin{array}{l}\text { Internet use for } \\
\text { communicating } \\
\text { with teachers } \\
\text { concerning } \\
\text { curriculum- } \\
\text { related concerns. }\end{array}$} & Never & 16 & 21 & 29 & 25 & 25 & 12 & 20 & \multirow[t]{5}{*}{26.86} \\
\hline & Rarely & 9 & 10 & 12 & 10 & 10 & 3 & 9 & \\
\hline & Sometimes & 5 & 4 & 7 & 17 & 17 & 7 & 4 & \\
\hline & Mostly & 1 & 6 & 3 & 5 & 5 & 0 & 1 & \\
\hline & Always & 2 & 1 & 6 & 2 & 2 & 2 & 2 & \\
\hline \multirow{2}{*}{$\begin{array}{l}\text { I am part of just a } \\
\text { family group }\end{array}$} & No & 9 & 12 & 16 & 20 & 20 & 8 & 11 & \multirow[t]{2}{*}{1.18} \\
\hline & Yes & 24 & 30 & 41 & 39 & 39 & 16 & 25 & \\
\hline \multirow{2}{*}{$\begin{array}{l}\text { I have a family } \\
\text { group for girls- } \\
\text { only }\end{array}$} & No & 12 & 15 & 18 & 18 & 18 & 5 & 6 & \multirow[t]{2}{*}{5.82} \\
\hline & Yes & 21 & 27 & 39 & 41 & 41 & 19 & 30 & \\
\hline \multirow{2}{*}{$\begin{array}{l}\text { Do you face any } \\
\text { kind of control } \\
\text { while using the } \\
\text { internet? }\end{array}$} & No & 20 & 19 & 25 & 28 & 28 & 13 & 25 & \multirow[t]{2}{*}{9.69} \\
\hline & Yes & 13 & 23 & 32 & 31 & 31 & 11 & 11 & \\
\hline \multirow{2}{*}{$\begin{array}{c}\text { In case you } \\
\text { experience } \\
\text { control, then do } \\
\text { you commit to it? }\end{array}$} & No & 25 & 21 & 27 & 29 & 29 & 13 & 23 & \multirow[t]{2}{*}{10.52} \\
\hline & Yes & 8 & 21 & 30 & 30 & 30 & 11 & 13 & \\
\hline \multirow{5}{*}{$\begin{array}{l}\text { I send messages } \\
\text { without } \\
\text { identifying the } \\
\text { source's } \\
\text { reliability. }\end{array}$} & Never & 17 & 19 & 28 & 30 & 30 & 14 & 17 & \multirow[t]{5}{*}{17.59} \\
\hline & Rarely & 6 & 7 & 9 & 14 & 14 & 5 & 9 & \\
\hline & Sometimes & 10 & 12 & 13 & 10 & 10 & 3 & 7 & \\
\hline & Mostly & 0 & 4 & 7 & 5 & 5 & 2 & 3 & \\
\hline & Always & 17 & 19 & 28 & 30 & 30 & 14 & 17 & \\
\hline \multirow{5}{*}{$\begin{array}{l}\text { I honestly share } \\
\text { the information } \\
\text { with my } \\
\text { classroom. }\end{array}$} & Never & 0 & 2 & 2 & 1 & 1 & 4 & 0 & \multirow[t]{5}{*}{42.28} \\
\hline & Rarely & 3 & 1 & 2 & 3 & 3 & 3 & 4 & \\
\hline & Sometimes & 5 & 9 & 7 & 6 & 6 & 0 & 3 & \\
\hline & Mostly & 8 & 9 & 19 & 8 & 8 & 4 & 12 & \\
\hline & Always & 17 & 21 & 27 & 41 & 41 & 13 & 17 & \\
\hline
\end{tabular}




\begin{tabular}{|c|c|c|c|c|c|c|c|c|c|}
\hline Items & Response & 6th & 7 th & 8th & 9th & 10th & 11th & 12th & \multirow{2}{*}{$\begin{array}{l}\text { Chi- } \\
\text { Square }\end{array}$} \\
\hline & & \multicolumn{7}{|c|}{ Frequencies } & \\
\hline \multirow{5}{*}{$\begin{array}{l}\text { I send messages } \\
\text { that insult others. }\end{array}$} & Never & 17 & 29 & 34 & 39 & 39 & 15 & 17 & \multirow[t]{5}{*}{35.17} \\
\hline & Rarely & 11 & 7 & 10 & 9 & 9 & 8 & 10 & \\
\hline & Sometimes & 5 & 4 & 5 & 4 & 4 & 1 & 4 & \\
\hline & Mostly & 0 & 1 & 6 & 3 & 3 & 0 & 4 & \\
\hline & Always & 0 & 1 & 2 & 4 & 4 & 0 & 1 & \\
\hline \multirow{2}{*}{$\begin{array}{l}\text { I use the internet } \\
\text { in a way to get } \\
\text { employment } \\
\text { through social } \\
\text { networks. }\end{array}$} & No & 10 & 20 & 18 & 21 & 21 & 10 & 16 & \multirow[t]{2}{*}{4.39} \\
\hline & Yes & 23 & 22 & 39 & 38 & 38 & 14 & 20 & \\
\hline
\end{tabular}

*Statistically Significant at $(\alpha \geq 0.05)$

Table 5 presents the frequencies and chi-square to answer the question; "Is there a statistically significant difference between female students' degree of using social networks and their grade level (six to twelfth grade)?" The table showed that there is an insignificant relationship between internet usage as a selflearning tool and female students' grades $(a \leq 0.05)$ for completing school homework (38.97) and honestly communicating answers (42.28). Similarly, other variables include the internet use for self-learning, cooperative learning, socialization with classmates, and teachers shares an insignificant relationship with the given values $38.97,25.05,4.39$, and 26.86, respectively. Other variables include exchanging family photos with peers, communication with teachers regarding curriculum issues, involvement in family groups, control over internet usage shares an insignificant relationship with their grade values with the given values of $7.60,26.86,1.18$, and 10.52 respectively. Similarly, sending messages regardless of resource reliability, honesty regarding the exchange of information through messages, along with ideas associated with the social networks, have insignificant relation with female students' grade level with the values of 17.59, 42.28, and 4.39 respectively. Jiang \& Zhao (2016), illustrated that female student was found to be more problematic regarding the use of mobile phone regarding the inappropriate use of the internet. However, the study found no significant difference between the use of mobile phones and students' grades.

The findings direct future researches to assess the internet use and electronic devices for assisting the students, teachers, and parents for better understanding the impact it has on the student's achievement as well as interpersonal relationships. It showed that the internet is used for socializing with family members and classmates as well as for self-learning.

\section{Conclusion}

The present study was aimed to investigate the impact which social media and the use of electronic devices have on the interpersonal relationship of the female students in Kuwait. It also examined whether the use of social media has an impact on the academic achievement of the students. It used a cross-sectional study design and recruited participants from 20 public schools in Mubarak 
Educational Area, Kuwait. It serves as a study limitation affecting the generalizability of the study findings. The survey results show that the internet helps in academic learning and sharing of ideas with others. Though the responses showed that students do not accept that their parents cannot control their internet usage, and if so, they do not commit to the controlled use of the internet.

The findings suggest that parents should develop a trustworthy relationship with their children and develop a relationship based on honesty and respect. Moreover, students should use the internet for their benefits, such as for communicating with their peers, classmates, and teacher. Moreover, since the researcher sent the post through WhatsApp; therefore, the honest response of students and the setting can be considered a limitation of the study. Likewise, the generalizability of the study is also affected by time and location. The study further suggests a follow-up study for a comprehensive analysis of the social networks and its impact on the student's achievement and interpersonal relations. It also recommends that future researches can recruit male participants at the same level for diversifying the study scope and expanding the research horizon.

\section{Acknowledgment}

The author is very thankful to all the associated personnel in any reference that contributed to/for this research. The author declares no conflict of interest. This research is not funded through any source.

\section{References}

Al-Barashdi, H. S., Bouazza, A., \& Jabur, N. H. (2015). Smartphone addiction among university undergraduates: a literature review. Journal of Scientific Research $\mathcal{E}$ Reports, 4(3), 210-225. https://doi.org/10.9734/jsrr/2015/12245

Alhazmi, A. K., \& Rahman, A. A. (2013). Facebook in higher education: Students' use and perceptions. Advances in Information Sciences and Service Sciences, 5(15), 32. https:// doi.org/10.24297/ijct.v12i3.3244

Baker, W. M., Lusk, E. J., \& Neuhauser, K. L. (2012). On the use of cell phones and other electronic devices in the classroom: Evidence from a survey of faculty and students. Journal of Education for Business, 87(5), 275-289. https:// doi.org/10.1080/08832323.2011.622814

Bartlett, R. M., \& Strough, J. (2003). Multimedia versus traditional course instruction in introductory social psychology. Teaching of Psychology, 30(4), 335-338. https://doi.org/10.1207/s15328023top3004_07

Bester, G., \& Brand, L. (2013). The effect of technology on learner attention and achievement in the classroom. South African Journal of Education, 33(2). https:// doi.org/10.15700/saje.v33n2a405

Cameron-Dow, J. (2009). Spinning the Web: The influence of the internet on the reporting of crime and criminal justice in traditional media. Theses, 16.

Castleman, B. L., \& Page, L. C. (2015). Summer nudging: Can personalized text messages and peer mentor outreach increase college going among low-income high school graduates?. Journal of Economic Behavior \& Organization, 115, 144-160.

https:// doi.org/10.1016/j.jebo.2014.12.008 
Cerretani, P. I., Iturrioz, E. B., \& Garay, P. B. (2016). Use of information and communications technology, academic performance, and psychosocial distress in university students. Computers in Human Behavior, 56, 119-126.

Curtis, A. (2013). The brief history of social media. The Brief History of Social Media.

De Leon-Abao, E., Boholano, H. B., \& Dayagbil, F. T. (2015). Engagement to social networking: Challenges and opportunities to educators. European Scientific Journal, 11(16).

De Sousa, L., Richter, B., \& Nel, C. (2017). The effect of multimedia uses on the teaching and learning of Social Sciences at the tertiary level: a case study. Yesterday and Today, 17, 1-22. https://doi.org/10.17159/2223-0386/2017/n17a1

Demirci, K., Akgönül, M., \& Akpinar, A. (2015). Relationship of smartphone use severity with sleep quality, depression, and anxiety in university students. Journal of behavioral addictions, 4(2), 85-92. https:// doi.org/10.1556/2006.4.2015.010

Dweikat, K. A. J. (2019). EFL Students' perceptions Of Whatsapp And Its Potential Benefits in Elt Practicum. Palestinian Journal of Technology and Applied Sciences (PJTAS), (2).

Eastman, H. (2016). Communication changes with technology, social media. Retrieved from http://universe. byu. edu/2013/07/07/1communication-changes-withtechnology-social-media/. accessed: August 30.

Egedegbe, N. (2013). The Effect of Social Networking Sites on Students' Academic Performance in Girne American University. North Cyprus.

Eginli, A. T., \& Tas, N. O. (2018). Interpersonal Communication in Social Networking Sites: An Investigation in the Framework of Uses and Gratification Theory. Online Journal of Communication and Media Technologies, 8(2), 81-104. https:// doi.org/10.12973/ojcmt/2355

El-Badawy, T. A., \& Hashem, Y. (2014). The impact of social media on the academic development of school students. International Journal of Business Administration, 6(1), 46. https:// doi.org/10.5430/ijba.v6n1p46

Englund, C., Olofsson, A. D., \& Price, L. (2017). Teaching with technology in higher education: understanding conceptual change and development in practice. Higher Education Research \& Development, 36(1), 73-87. https:// doi.org/10.1080/07294360.2016.1171300

Ferreira, V. M., \& Ramos, F. (2014). Improving Teacher-Student Contact in a Campus through a Location-Based Mobile Application. International Association for the Development of the Information Society.

Fuller, R., \& Joynes, V. (2015). Should mobile learning be compulsory for preparing students for learning in the workplace? British Journal of Educational Technology, 46(1), 153-158. https://doi.org/10.1111/bjet.12134

Gdanetz, L. M., Hamer, M. K., Thomas, E., Tarasenko, L. M., Horton-Deutsch, S., \& Jones, J. (2018). Technology, educator intention, and relationships in virtual learning spaces: a qualitative metasynthesis. Journal of Nursing Education, 57(4), 197-202. Doi: https://doi.org/10.3928/01484834-20180322-02

He, Z., Shao, S., Zhou, J., Ke, J., Kong, R., Guo, S., \& Song, R. (2014). Does long time spending on the electronic devices affect the reading abilities? A cross-sectional study among Chinese school-aged children. Research in developmental disabilities, 35(12), 3645-3654. https://doi.org/10.1016/j.ridd.2014.08.037

Helou, A. M., \& Rahim, N. Z. A. (2014). The influence of social networking sites on students' academic performance in Malaysia. International Journal of Electronic Commerce, 5(2), 247-254. https://doi.org/10.7903/ijecs.1114 
IBM Offical Website. (2018). IBM SPSS Statistics 20.0 Release Notes. Retrieved from https://www.ibm.com/support/pages/ibm-spss-statistics-200-releasenotes\#relnotes_description

Jiang, Z., \& Zhao, X. (2016). Self-control and problematic mobile phone use in Chinese college students: The mediating role of mobile phone use patterns. BMC psychiatry, 16(1), 416. https://doi.org/10.1186/s12888-016-1131-z

Kiatrungrit, K., \& Hongsanguansri, S. (2014). Cross-sectional study of use of electronic media by secondary school students in Bangkok, Thailand. Shanghai archives of psychiatry, 26(4), 216. https://doi.org/10.1037/t65501-000

Lee, K. R. (2013). Impacts of Information Technology on society in the new century, 2012. Retrieved from https://www.zurich.ibm.com/pdf/news/Konsbruck.pdf.

Li, S., Palonen, T., Lehtinen, E., \& Hakkarainen, K. (2019). Face-to-face Contacts, Facebook Connections and Academic Support: Adolescents' Networks between and across Gender and Culture in Finland. YouNg, 27(2), 184-200. https:// doi.org/10.1177/1103308818766773

Malik, S., \& Agarwal, A. (2012). Use of multimedia as a new educational technology toolA study. International Journal of Information and Education Technology, 2(5), 468. https://doi.org/10.7763/ijiet.2012.v2.181

Manasijević, D., Živković, D., Arsić, S., \& Milošević, I. (2016). Exploring students' purposes of usage and educational usage of Facebook. Computers in Human Behavior, 60, 441-450. https://doi.org/10.1016/j.chb.2016.02.087

Naizabekov, S. (2012). Negative impact of social networking sites on academic performance of students. Academia. edu. https://doi.org/10.21275/v4i12.nov152163

Nikken, P., \& Schols, M. (2015). How and why parents' guide the media use of young children. Journal of child and family studies, 24(11), 3423-3435. https://doi.org/10.1007/s10826-015-0144-4

Nowell, S. D. (2012). Stories of digital lives: Teacher-student relationships in secondary classrooms and digital spaces (Doctoral dissertation, Oklahoma State University). https:/ / doi.org/10.1080/09523987.2014.924661

Pardo, A. (2013). Social learning graphs: combining social network graphs and analytics to represent learning experiences. International Journal of Social Media and Interactive Learning Environments, 1(1), 43-58. https:// doi.org/10.1504/IJSMILE.2013.051652

Pickering, J. D., \& Bickerdike, S. R. (2017). Medical student use of Facebook to support preparation for anatomy assessments. Anatomical sciences education, 10(3), 205214. https://doi.org/10.1002/ase.1663

Rabiu, H., Muhammed, A. I., Umaru, Y., \& Ahmed, H. T. (2016). Impact of mobile phone usage on academic performance among secondary school students in Taraba State, Nigeria. European Scientific Journal, ESJ, 12(1), 466. https://doi.org/10.19044/esj.2016.v12n1p466

Raskauskas, J., \& Stoltz, A. D. (2007). Involvement in traditional and electronic bullying among adolescents. Developmental psychology, 43(3), 564. https:/ / doi.org/10.1037/0012-1649.43.3.564

Rideout, V. (2012). Children, teens, and entertainment media: The view from the classroom. Retrieved from Common Sense Media website: https://www. commonsensemedia. org/research/children-teens-and-entertainment-media-the-viewfrom-the-classroom. https:/ / doi.org/10.17645/mac.v4i3.515

Rosen, L. D., Lim, A. F., Felt, J., Carrier, L. M., Cheever, N. A., Lara-Ruiz, J. M., \& Rokkum, J. (2014). Media and technology use predicts ill-being among children, preteens and teenagers independent of the negative health impacts of exercise 
and eating habits. Computers in human behavior, 35, 364-375.

https://doi.org/10.1016/j.chb.2014.01.036

Shah, I., \& Khan, M. (2015). Impact of multimedia-aided teaching on students' academic achievement and attitude at elementary level. US-China Education Review A, 5(5), 349-360. https:// doi.org/10.17265/2161-623x/2015.05a.006

Sharpe, D. (2015). Your chi-square test is statistically significant: now what? Practical Assessment, Research \& Evaluation, 20.

Sheldon, P. (2016). Facebook friend request: Applying the theory of reasoned action to student-teacher relationships on Facebook. Journal of Broadcasting \& Electronic Media, 60(2), 269-285. https:// doi.org/10.1080/08838151.2016.1164167

Shifflet, R., \& Weilbacher, G. (2015). Teacher beliefs and their influence on technology use: A case study. Contemporary Issues in Technology and Teacher Education, 15(3), 368-394.

Srivastava, T. K., Waghmare, L. S., Jagzape, A. T., Rawekar, A. T., Quazi, N. Z., \& Mishra, V. P. (2014). Role of information communication technology in higher education: Learners perspective in rural medical schools. Journal of clinical and diagnostic research: JCDR, 8(6). XC01.

https:// doi.org/10.7860/jcdr/2014/8371.4448

Stewart, J., \& Williams, R. (2000). The Co-Evolution of Society and Multimedia Technology. In Social Dimensions of Information Technology: Issues for the New Millennium (pp. 46-62). IGI Global. https://doi.org/10.4018/978-1-878289-865.ch004. 